African Journal of Educational Studies in Mathematics and Sciences Vol. 6, 2008

\title{
The challenges of integrating scientific literacy into the functional literacy programme in Nigeria
}

\author{
Olatoye, R. A. ${ }^{8}$
}

\begin{abstract}
The basic understanding of science that should be possessed by everyone not only professionals in science is called scientific literacy. This paper focuses on the need to integrate scientific literacy into the functional literacy programme in Nigeria. Ability to read and write alone without scientific literacy will make learners to be victims of superstition and taboos. Learners who are scientific illiterate are also likely to be confused by events happening around them and also unable to make some informed decisions about some issues in their daily lives. It is argued that a person is not completely literate until scientifically literate. Nigeria should borrow a leaf from the United States of America who despite high level of scientific literacy are still projecting into the future not only to make their citizens to be able to read and write alone but to be scientifically literate. There is therefore the need to project into the future and work out plans to make Nigerian citizens scientifically literate. In order to realise these plans, there are basic issues and challenges that should be tackled. These are funding, curriculum design and implementation, language barriers and means of communication, exceptional children participation, gender, rural and urban factors and monitoring and evaluation of programme impact.
\end{abstract}

Keywords: $\quad$ scientific literacy, functional funding, curriculum design, curriculum implementation, language barriers

\section{Introduction}

Literacy is simply defined as ability to read and write (Hornby, 1995). Over the years, there have been other different definitions of literacy. It is true that a literate person should basically know how to read and write, however literacy has different levels. Akintayo \& Oghenekohwo (2004) asserted that literacy could operate at different levels to the extent that someone literate at one level may not be literate at another level. Therefore it is possible for somebody, though able to read and write yet can either be socially or politically illiterate.

${ }^{8}$ Dr. Olatoye, R. A. lectures at the Department of Science, Technology and Mathematics Education, College of Education, Ipetu-Ijesa Campus, Osun State University, Osogbo, Osun State, Nigeria. E-mail: kingdemola@yahoo.com. 
The challenges of integrating scientific literacy into the functional literacy programme in Nigeria Olatoye, R. A.

UNESCO (1962) noted that for a person to be functionally literate he or she must be able to engage in all those activities in which literacy is required for effective functioning in his or her group and community. The attainments in reading, writing and computation should be used towards personal and community development. A person's level of literacy should not be dependent on situation but rather as a relatively fixed and observable quality. It is clear that a person though may be able to read and write, yet lacks some basic knowledge to live and function effectively in his community. Fafunwa (1974) described an illiterate individual as invariably a poor consumer of goods, a pawn in the hands of unscrupulous politicians and a victim of superstition and magic.

At the Teheran Conference of 1962, the International Community under the auspices of UNESCO floated a new approach to literacy known as functional literacy. This approach has economic production with the objectives of providing instruction in reading and writing being integrated with training. This has attendant immediate benefits to the learners.

\section{Who is a functionally literate person?}

A functionally literate person therefore is a person who is able to read and write and also able to use the knowledge acquired to gain more basic knowledge that is fundamental to function effectively in his/her community. It is common to hear people saying something like this: 'educated illiterates' or 'he passed through school but the school did not pass through him'. A person that is functionally literate is both educated and literate. He/she is cultured and a model example of fulfillment of the objectives of mass literacy programme.

Today, many people that claim to be literates still hold some views and opinions that are merely superstitious and fallacious. This category of people through may be able to read or write, yet still require education in other areas of life. I was shocked when somebody who holds a higher degree said 'Ninety-five percent of what makes up a child comes from the mother'. Another educated person said 'I would have married that woman in those days, but I didn't. She gave birth to twins. If I had married her, she would have given birth to twins for me'. Those who understand basic biology know that these statements are not true.

No doubt, the world today is science-oriented. Nigerians cannot therefore be said to be functionally literate if science concepts, skill and knowledge are not acquired as part of experiences in a school. (Olatoye, 2002). Scientific discoveries affecting everybody in homes and offices are appearing daily. In a world that is already technologically-oriented, a basic knowledge of science as well as technology will make each Nigerian better adjusted to living in the computer and electronic information age. All learners therefore should have basic knowledge of science so that they can read and understand science news and converse intelligently about current scientific development. This will enable individuals to make informed decisions on their daily lives and to function effectively as citizens. 


\section{What is Scientific Literacy?}

The basic understanding of science that should be possessed by everyone, not only professionals in scientific and physical fields are frequently referred to as scientific literacy. (Klopfer, 1995). The development of scientific literacy is a central concern of science education in all its ramifications. Knowledge of scientific concepts can be gained in formal instructions given students in secondary schools and tertiary institutions and also in the less formal teaching that takes place in science museums and sciencetechnology centres.

Scientific literacy is the knowledge and understanding of scientific concepts and processes required for personal decision-making, participation in civic and cultural affairs, and economic productivity (National Research Council, 1996). Scientific literacy is composed of five basic components:

a. Knowledge of significant science facts, concepts, principles and theories.

b. Ability to apply relevant knowledge in everyday life;

c. Ability to utilize the processes of scientific inquiry;

d. An understanding of general ideas about the characteristics of science and the important interactions of science, technology and society;

e. The possession of informed attitudes and interest related to science.

Science educators (Erinosho, 2004; Ivowi, 1990; Klopfer, 1995) are of the opinion that when people's understanding and skills expressed in these components are fully developed, learners can function successfully in a contemporary technology-based society. Without this literacy in science, people are likely to be confused by many events that happen in the world and less likely to enjoy healthy and secured lives.

The goal of any society therefore should be to develop as well as encourage scientific literacy among its citizens. It is only when significant percentage of Nigerian citizens is scientifically literate that science can be used as the vehicle for development. It is also by strengthening the scientific skills of the citizens that they will be empowered to solve myriad problems that confound the nation whether in agriculture, health, environmental management and disease control

Moreover, it is becoming more evident that for any nation to keep pace with the global technological advances, she must develop a mass of people that understand science and can effectively use the knowledge. Therefore, through scientific enterprise, innovations and invention would emerge that could translate into practical terms through technological breakthrough for the advancement of humans. This is very important to fully realize the objectives of science education, which include production of a scientifically literate society. Facts and figures on mass and scientific literacy programmes should give all education stakeholders vision to project into the future.

The Federal Government has inaugurated National Commission for Mass Literacy. The objective of the commission is to make nearly 50 million Nigerian illiterates functionally literate by 2005 AD (FRN, 1998). UNESCO put the percentage of Nigerians who are still 
The challenges of integrating scientific literacy into the functional literacy programme in Nigeria

Olatoye, R. A.

unable to read and write at $48 \%$. Data on literacy rate indicate that the actual numbers of illiterates have remained constant over the last two or three decades due to population growth (UNESCO, 2004). The UNESCO report estimated 962 million illiterates in the world in 1990, 885 million in 1995, and 887 million in 2000 constituting $27 \%$ of the adult population in the developing countries. Regionally, UNESCO (2004) further estimated that Eastern and Southern Asia have the highest number of illiterate population. The subSaharan African and Arab regions have about the same (40\%) adult illiteracy rate with Latin America at about half of this rate. Many countries of the world are still working, tireless to make more number of their citizens literate.

Nigeria needs to learn from the United States of America. The American Association of Advancement of Science (AAAS) is already projecting to consider all technological changes that will transform the world by the time Halley's Comet returns in 2061. All the projects proposed by AAAS have scientific literacy at their background. The projects are:

(a) Scientific Literacy for All Americans

(b) National Science Education Standards and

(c) Benchmarks for Science Literacy

Benchmarks for Science Literacy published by AAAS (1993) also reported in Akpan (1996) has the following items stated below:

- Literacy in science, mathematics and technology helps people live interesting, responsible and productive lives.

- $\quad$ Curriculum reform should be shaped by a vision of the lasting knowledge and skills the nation wants students to acquire by the time they become adults.

- $\quad$ To learn science and technology very well, there should be reduction in the sheer amount of materials now being covered.

- Goals should be stated so as to reveal the intended character and sophistication of learning in science. Mathematics, science and technology (in an integrated form) should centre on science literacy, not on an understanding of each of the separate disciplines.

- Common goals do not require uniform curricula, teaching methods and materials.

- $\quad$ Reform must be comprehensive and long-term, if it is to be significant and lasting. It must centre on all children, all grades and all subjects.

\section{Making use of simple experiments and illustrations in scientific literacy lessons}

In inculcating scientific literacy into the functional literacy programme, the amount of details students are expected to learn should be relatively less than what professionals who are majoring in the subjects. The materials should therefore be presented in a simple form with practical illustrations and examples that will enhance mastery of specific scientific concepts. 
Science educators should bear in mind that there are three types of scientific literacy. Shem (1975) identified three types of scientific literacy; practical, civic and cultural matters a shelter, diet, child rearing, water and food supply. Civic scientific literacy enables citizens to contribute to debates about a range of science-related issues of public policy (e.g. fluoridation of drinking water, nuclear power or contraception). Cultural scientific literacy is concerned with an understanding and appreciation such scientific concepts like atomic theory. Scientific literacy is therefore concerned with health, recreation, safety at work, domestic energy management, and so on.

Olatoye and Oyundoyin (2001) asserted that scientific literacy should be able to provide scientific explanation to many events happening around us. This is very important because some cultural beliefs are antagonistic to scientific proofs and this affects the students even in the science class. Scientific literacy should be able to provide answers to some frequently asked questions. It will be interesting to know answers to the following questions in the scientific literacy class:

(a) What is actually happening when there is appearance of rainbow in the sky?

(b) What actually is happening when the sun is shining and it is raining at the same time? Is it that leopards are giving birth as believed in some culture?

(c) Fish dropping from the sky: a myth or reality?

Many people give different explanations for the appearance of rainbow in the sky. Science teachers in literacy classes should be able to explain the concept of refraction. This can be demonstrated and illustrated. Water can poured be into a transparent container, a stick can be dipped inside it. The stick will appear bent at the surface of the water. This can be used to teach real and apparent depth in refraction of light rays. Light rays passing through a prism being refracted and breaking the light rays into different colours can also be demonstrated. When these simple experiments are carried out then, the scientific explanation for the appearance of rainbow can then be given. Rainbow occurs when it has just rained and there are droplets of water in the atmosphere. The sun appears, producing light rays which pass through the water droplets and then refracted into the sky breaking into different colours otherwise known as rainbow.

One of the reasons for scientific literacy is to enable learner make informed decision. The transfer of sickle cell genotype can also be illustrated. This will help them to make informed decision about who to marry and or to counsel intending couples.

The likely offspring (or children) that can emerge when people of different genotypic groups marry one another can be explained and illustrated. For example, if an AS father (carrier) marries another AS mother (also a carrier), the probability that they will give birth to a sickler is $1 / 4$. If this group of people are already married and are fortunate to have two children who are not sicklers they should be advised to stop giving birth to children. The illustration is presented in Figure 1. 
The challenges of integrating scientific literacy into the functional literacy programme in Nigeria Olatoye, R. A.

Father (AS)

\begin{tabular}{|c|c|c|}
\hline & A & S \\
\hline A & AA Normal & AS Carrier \\
\hline $\mathrm{S}$ & AS carrier & SS Sickler \\
\hline
\end{tabular}

\section{Figure 1}

Likely offspring from people of different genotypic groups

Many other experiments can be illustrated. For example experiments to show the percentage of oxygen in the air and relative density of liquids will make students in scientific literacy class to understand why ordinary water cannot be used to put off fire from petrol. Inculcating scientific literacy into the functional literacy class will not only make students to be able to read and write but to also provide scientific explanation to events happening around them so that they can function effectively in the society rather than being victims of superstition and taboos. Some people today do not believe in the existence of Acquired Immuno Deficiency Syndrome (AIDS) because they cannot just imagine the world of the 'invisible', which is the world of micro-organisms. How can something one cannot even see then be so strong to kill just by their presence on a syringe or needle? Scientific literacy no doubt will help in eradication of communicable and even non-communicable diseases. An individual is not completely literate until scientifically literate.

\section{Basic issues and challenges in policy implementation of functional and scientific literacy programmes}

According to Section7, No 77 of the Federal Republic of Nigeria (1998), the following steps are expected to be taken to eradicate illiteracy at the shortest possible time:

(a) There shall be a nation-wide mass literacy campaign based on various strategies including that of "each-one-teach-one" or "Fund-the -teaching-of-one".

(b) State agencies for mass education, shall be responsible for the regulation of all adult classes.

(c) Mass literacy, adult and non-formal education shall continue to be under the supervision of ministries of education

(d) Mass literacy programmes shall be provided free to the beneficiaries.

When scientific literacy programme is fully integrated into the mass literacy programme. The science educators handling the literacy classes should intensify efforts to encourage the learners to make sure they teach others and support the funding of teaching others. A close examination of the steps listed above will readily raise some basic issues and challenges. Such issues and challenges include funding curriculum design, language barrier and means of communication, exceptional children participation, gender, rural and urban factors and evaluation of programme impact. 


\section{The challenges of integration}

\section{Funding of mass literacy programme}

In Nigeria, governments at all levels are not allocating significant percentage of their budget on education to adult and non-formal education. Borode (2004) observed that the Federal Government has failed to implement No 8 of the UNESCO, Tokyo conference recommendations that the member states should allocate a sufficient percentage of the national budget to adult and non-formal education, he presented the breakdown of allocation to adult and non-formal education which has always been between $2 \%$ and $5 \%$ of the overall federal budgetary allocation to education. In Oyo state, the highest allocation in the recent years was $1.9 \%$ of the total allocation to education. While appeal is being made to the Government at all levels especially the Ministries of Education to increase allocation to adult and non-formal education, it should be noted that government alone cannot fund education. There should be public enlightenment campaign and appeal for fund for mass literacy programme. Professional associations, international agencies, co-operate bodies are hereby enjoined to join in funding literacy programme in Nigeria.

\section{Curriculum Design and Implementation}

The curriculum that will integrate scientific literacy into the mass literacy programme should consider the learner, the society and the learning environment. The primary focus should be on the learner. There is need to have human and material resources for the execution of the literacy programme.

Sarumi (1999) noted that literacy instructors make use of reading materials which do not meet the needs and interest of adult learners. There is need to prepare simple, easy-toread texts that will give practical illustrations of some scientific facts and make use of practical examples that would stimulate the interest of the learners to know more. Such texts can only be prepared by science educators and experts in adult education. Curriculum, no matter how well designed cannot be properly implemented without necessary human, financial and material resources.

\section{Language Barrier and means of communication}

Nigeria is a multilingual country with about 490 indigenous languages (Omodiaogbe, 1992). The challenge of covering every ethnic/language group in the country is a great

challenge. Instructors should understand English Language and the local language of the learners. The challenge is great when scientific words and phrases such as sickle cell, oxygen and refraction are translated or explained in the local languages.

\section{Adequate Coverage of the Urban and Rural Areas}

Rural areas are especially disadvantaged when it comes to mass literacy campaign. The data of literacy rates of population age 15-24 years show that literacy rate is higher in urban than rural areas (National Population Commission, 1991; Akintayo \& Oghenekohwo, 2004). In Nigeria, the literacy rate in urban areas is as high as $84.9 \%$ 
The challenges of integrating scientific literacy into the functional literacy programme in Nigeria

Olatoye, R. A.

while rural area is $62.1 \%$. There is therefore the challenge of greater mobilization of rural dwellers to participate in the literacy programme.

\section{Gender Factor in Literacy Programme}

UNESCO (1991) put general world literacy level at $73.5 \%$. Males are generally more literate than females (Male $=80.6 \%$, females $=66.4 \%$ ). In Nigeria, the literacy rate for age $15-24$ years is $71.2 \%$ ( $90.6 \%$ for males, $62.5 \%$ for females). Males generally perform better than females in an international study of science achievement (Keeves, 1992). It is therefore necessary to make conscious effort to carry along female learners in order to bridge the already existing gaps.

\section{Participation of Exceptional Children}

Nwazuoke (2000) noted that about $10 \%$ of every country's population are persons with disability. He said that society has all along pretended that all its members are 'normal' or able-bodied and therefore put in place measures, which are protective of the rights and privileges enjoyed generally by its able-bodied members. Olatoye and Oyundoyin (2002) while advocating for scientific literacy campaign among children with special needs pleaded for provision of adequate materials such as auditory services materials and deaf instructors for the deaf, braille for the blind, chalkboard and radio cassettes for the mentally retarded and competent teachers to handle the gifted.

\section{Monitoring and evaluation of the of impact literacy programme}

Evaluation is a basic requirement for improving programme performance. Imhabekhai (2004) asserted that programme evaluation provides programme managers necessary information about input, process and output situation. It is through programme evaluation that programme managers can ascertain the relative contribution of each component of the inputs. Result of evaluation can be useful in making necessary changes that facilitate the attainment of programme objectives. Monitoring should be done regularly to ensure effectiveness of the programme.

\section{Conclusion}

United States of America with high level of literacy and technological attainment would still not hesitate to put in place functional projects to enhance scientific literacy. Nigeria should therefore also put in place workable plans for scientific literacy with immediate effect so that her citizens could converse intelligently and also compete favourably with other citizens from other parts of the world. There is need to release fund and develop curriculum relevant for this purpose. There is need for public enlightenment campaign and sponsored programmes to facilitate the realization of the objectives of functional and scientific literacy programmes. 


\section{References}

Akintayo, M.O. \& Oghenekohwo J.E. (2004). Functional Literacy: Issues and Perspectives.International Journal of Literacy Education Ibadan: Department of Adult Education, University of Ibadan. 1(2) pp1-21.

Akpan, B.B. (1996). Towards a reduction in the contents of our primary and secondary science curricula. Journal of the Science Teachers Association of Nigeria. Vol. 31, Nos $1 \& 2$ pp $1-5$.

American Association for Advancement of Science - AAAS (1993). Benchmark for Science Literacy Washington D.C.: Oxford University Press.

Borode, M. (2004). Trend in budgetary allocation to adult and non-formal education unit in Oyo State (1996-200). International Journal of literacy Education Department of Adult Education University of Ibadan 1(3) pp 29-36.

Erinosho, S.Y. (2004). Teaching Science Beyond the Classroom four-walls. In: Afemikhe, O.A.\& Adewale, J.G. (Eds.) Issues in Educational Measurement and Evaluation in Nigeria. Ibadan: Institute of Education pp165-179.

Fafunwa, A.B. (1974). History of Education in Nigeria. Ibadan: NPS Educational Publishers Limited.

Federal Republic of Nigeria (1998) National Policy of Education (Revised). Abuja: NERDC.

Hornby, A.S. (1995). Oxford Advanced Learner's Dictionary 5thed. Oxford: Oxford University Press.

Imhabekhai, C.I. (2004). Post course evaluation in Adult and non-formal Education. In: Afemikhe, O.A. \& Adewale, J.G. (Eds). Issues in Educational Measurement and Evaluation in Nigeria. Ibadan: Institute of Education . pp 233-241.

Ivowi, U.M.O. (1990). The philosophy and objectives of the science and mathematics curricula at the senior sedentary school level in Nigeria. Journal of Science Teachers' Association 26(2) pp3-8

Keeves J.P. (1992). Learning Science in the Changing World: Cross-national studies of science achievement 19970-1984. Australia: IEA International Headquarters.

Klopfer, L.E. (1995). Scientific Literacy. In: Husen T. \& Postlethwaite, T.N. (Eds.) The International Encyclopedia of Education. Oxford: Pergamon Press.

National Population Commission (1991). Population Reports. Lagos: NPC

National Research Council (1996). National Science Education Standards. Washington D.C.: National Academy Press.

Nwazuoke, I.A. (2000). Constitutional rights of persons with disabilities in Nigeria. The Journal of the National Council for Exceptional Children. 4(1,2), p.v.

Olatoye, R.A. \& Oyundoyin, J.O. (2001). Scientific literacy Campaign among children with special needs. Nigerian Journal of Clinical and Counselling Psychology. Vol 7, Issues 1 and 2 pp 55-64.

Olatoye, R.A. (2002). A causal model of school factors as determinants of science achievement in Lagos State. An Unpublished PhD Thesis. University of Ibadan, Ibadan. 
The challenges of integrating scientific literacy into the functional literacy programme in Nigeria

Olatoye, R. A.

Omodiaogbe, S.A. (1992). 150 years on: English in the Nigerian School system, present and future. ELT journal, 46(1). Pp 19-28

Sarumi, A. (1999). Adult Literacy: A key to the $21^{\text {st }}$ century. In Obemeata, J.O., Ayodele, S.O., Araromi, M.A. (Eds). Evaluation in Africa Ibadan: Stirling-Horden Publishers (Nig). Limited.

Shem, B. (1975). Scientific literacy and public understanding of science. In Day, S.B. (Ed). Communication of Scientific Information Basel: Karger AG.

UNESCO, (1962). World Education Report, Paris: UNESCO

UNESCO, (1991). World Education Report, Paris: UNESCO

UNESCO, (2004) EFA Global Monitoring Reports. Paris: UNESCO 